\title{
PELATIHAN MODEL PEMBELAJARAN BAGI GURU-GURU BAHASA JEPANG DI MANADO
}

\author{
Sherly Ferro Lensun \\ Jurusan Bahasa Jepang, Fakultas Bahasa dan Seni, \\ Universitas Negeri Manado \\ sherlylensun@unima.ac.id
}

\begin{abstract}
Abstrak
Pelaksanaan pelatihan ini bertujuan, terutama untuk menghasilkan kualitas pengajaran para guru dengan melakukan kegiatan pelatihan penggunaan model-model pembelajaran pembelajaran yang bervariasi untuk meningkatkan semangat dan motivasi siswa dalam belajar. Dengan adanya kegiatan pelatihan ini diharapkan dapat memberikan tambahan pengetahuan dan informasi kepada para guru-guru untuk meningkatkan kualitas dalam pengajaran karena pembelajaran dengan berbagai macam media pembelajaran, merupakan solusi bagi beragam masalah pendidikan. Sasaran pelatihan yang akan dilibatkan dalam kegiatan ini yaitu seluruh Guru-guru bahasa Jepang/MGMP Manado. Menerapkan model-model pengajaran yang koopratif yang mudah diserap oleh pembelajar adalah upaya pengajar untuk mencapai tujuan yang diharapkan yaitu dapat menguasai empat ketrampilan berbahasa yakni; ketrampilan berbicara, membaca, menulis, menyimak. Kegiatan pengabdian pada masyarakat dalam bentuk pelatihan penggunaan media pembelajaran yang bervariasi kepada Guru-guru bahasa Jepang/MGMP Manado telah berhasil dilaksanakan dengan baik.

Pelaksanaan pelatihan ini telah mencapai tujuan yang dilaksanakan karena semua peserta dapat menguasai dan membuat media pembelajaran yang bervariasi
\end{abstract}

Kata kunci : Bahasa, Jepang, Pembelajaran,model.

\section{PENDAHULUAN}

\section{A. ANALISIS SITUASI}

Cara mengajar yang menarik akan membuat siswa tidak bosan, oleh sebab itu pengajar harus pandai memilih media pengajaran yang tepat. Tren pembelajaran yang terkini adalah pembelajaran kontekstual. Guru profesional adalah orang yang memiliki kemampuan dan keahlian khusus dalam bidang keguruan sehingga ia mampu melakukan tugas dan fungsinya sebagai guru secara maksimaI. Dengan kata lain guru profesional adalah orang yang terdidik dan terlatih dengan baik serta memiliki pengalaman yang kaya di bidangnya. Yang dimaksud dengan terdidik dan terlatih bukan hanya memilki pendidikan formal tetapi juga harus menguasai berbagai strategi atau teknik dalam KBM serta landasan-landasan kependidikan seperti tercantum dalam kompetensi guru dalarn uraian selanjutnya. Dalam melakukan kewenangan profesionalismenya, guru dituntut memiliki seperangkat kemampuan (kompetensi) yang beraneka ragam. Namun sebelum sampai pada pembahasan kompetensi ada beberapa syarat profesi yang harus dipahami terlebih dahulu. Mengingat tugas guru yang demikian kompleksnya, maka 
profesi ini memerlukan persyaratan khusus sebagai berikut:1. Menuntut adanya keterampilan yang berdasarkan konsep dan teori ilmuÂ pengetahuan yang mendalam 2 . Menekankan pada suatu keahlian dalam bidang tertentu sesuai dengan bidang profesinya. 3.Menuntut tingkat pendidikan keguruan yang memadai. 4. Adanya kepekaan terhadap dampak kemasyarakatan dari pekerjaan yang dilaksanakannya 5. Memungkinkan perkembangan sejalan dengan dinamika kehidupannya. Untuk itulah seorang guru harus mempersiapkan diri sebaik-baiknya untuk memenuhi panggilan tugasnya, baik berupa in-service training (diklat/penataran) maupun pre-service training (pendidikan keguruan secara formal).

Seorang pengajar, perlu membekali dirinya dengan pengetahuan yang baik tentang bidang studi yang harus diajarkannya dan mempersiapkan model pembelajaran yang lebih inovatif, termasuk cara pengajaran, media pengajaran dan lainlain, agar tujuan pembelajaran dapat tercapai. Belajar secara kontekstual adalah konsep belajar yang membantu guru mengaitkan materi pembelajaran dengan situasi dunia nyata peserta didik, dan mendorong peserta didik membuat hubungan antara pengetahuan yang dimilikinya dengan penerapannya dalam kehidupan sehari-hari (Masnur Muslich: 2007). Proses belajar yang monoton dan hanya berlangsung satu arah merupakan salah satu faktor penyebab rendahnya hasil belajar pembelajar. Kesulitan belajar yang dihadapi pembelajar, tidak hanya muncul dari segi materi saja, tetapi kesuliltan belajar dapat muncul karena pengaruh faktor dalam bagi pembelajar, seperti motivasi, minat dan kondisi physikologi dan faktor luar bagi pembelajar, seperti lingkungan sekolah, keluarga dan teman.

Pembelajaran merupakan suatu sistem yang terdiri atas berbagai komponen yang saling berhubungan satu dengan yang lain. Komponen tersebut meliputi ; tujuan, materi, metode, dan evaluasi. Keempat komponen tersebut harus diperhatikan oleh pengajar dalam memilih dan menentukan model-model pembelajaran apa yang akan digunakan dalam kegiaatan pembelajaran.

Joice dan Weil (1980 : 1) Model pembelajaran diartikan sebagai prosedur sistematis dalam mengorganisasikan pengalaman belajar untuk mencapai tujuan belajar. Dapat juga diartikan sebagai suatu pendekatan yang digunakan dalam kegiatan pembelajaran . Model pembelajaran adalah suatu rencana atau pola yang dapat digunakan untuk membentuk kurikulum atau rencana pembelajaran jangka panjang , merancang bahan-bahan pembelajaran dan membimbing pelajaran di kelas atau yang lain.

\section{B. PERMASALAHAN MITRA}


Sebagai mitra dalam pelaksanaan kegiatan pengabdian pada masyarakat ini adalah seluruh pengajar bahasa Jepang di Sulawesi Utara. Permasalahan yang teridentifikasi yang menjadi titik tolak kegiatan pengabdian pada masyarakat yang diusulkan ini terfokus pada beberapa masalah yang dihadapi oleh mitra yaitu :

1. Peningkatan kualitas pengajaran bagi pengajar bahasa Jepang agar ada jalan solusi ketika mahasiswa/siswa menganggap mata pelajaran bahasa Jepang lebih khusus pelajaran kanji sulit.

2. Para pengajar kurang mengeksplorasi metode, model pembelajaran yang cocok dan efektif sehingga mahasiswa/siswa tertarik belajar bahasa Jepang.

\section{METODE PELAKSANAAN}

\section{A. Target}

Berdasarkan latar belakang pemikiran dan konteks permasalahan yang ada, maka pelaksanaan pelatihan ini bertujuan, terutama untuk menghasilkan pengajar yang berpengetahuan, berkemampuan dan memiliki ketrampilan ; mengajar yang baik, yang mudah diserap oleh para pembelajar.

Menerapkan metode-petode pengajaran yang menarik dan yang mudah diserap oleh pembelajar adalah upaya pengajar untuk mencapai tujuan yang diharapkan yaitu dapat menguasai empat ketrampilan berbahasa yakni; ketrampilan berbicara, membaca, menulis, menyimak.

\section{B. Luaran}

Luaran yang diharapkan melalui pelaksanaan kegiatan pengabdian pada masyarakat ini adalah sebagai berikut :

1. Peningkatan kualitas sumber daya manusia yakni seluruh pengajar bahasa Jepang wilayah kota Manado.

2. Melalui kegiatan ini diharapkan para pengajar bahasa Jepang dapat memiliki pengetahuan yang positif dalam rangka upaya peningkatan kemampuan pengajaran dengan menggunakan model pembelajaran yang cocok, sehingga peserta didik tidak membosankan. Dan dapat menghasilkan tenaga pengajar yang handal dan terampil dalam mengajar bahasa Jepang.

3. Melalui kegiatan ini target luaran adalah akan dihasilkan modul atau bahan ajar tentang model-model Pembelajaran Jepang yang inovatif beserta dengan media pembelajaran.

\section{METODE PELAKSANAAN}

\section{A. Metode Kegiatan}

Pelaksanaan Iptek pada masayarakat ini adalah workshop pengajaran berbagai macam metode pengajaran yang inovatif dan menyenangkan bagi pengajar bahasa Jepang yang ada di sulawesi Utara. Kegiatan ini bertujuan untuk membekali pengetahuan pengajaran huruf Jepang yang 
efektif. Sehingga ketika timbul permasalahan-permasalahan dalam proses pembelajaran para pengajar dapat mengatasi.

Berdasarkan permasalahan di atas sehingga workshop bagi pengajar bahasa Jepang perlu untuk dilaksanakan agar dapat menstimulasi pengembangan kreatifitas pengajar bahasa Jepang yang ada di Sulawesi Utara. Metode yang digunakan dalam kegiatan penyuluhan yang dilaksanakan relevan dengan pokok permasalahan yang disesuaikan dengan tujuan yang ingin dicapai adalah yaitu metode presentasi, tanya jawab, demonstrasi dan pemberian tugas. Rancangan Evaluasi dilakukan mulai awal pelatihan sampai akhir pelatihan. Kriteria, indicator dan tolak ukur evaluasinya adalah sebagai berikut :

1. Kriteria yang digunakan dalam penilaian :

a. Apabila capaian nilai $>75 \%$ dari tujuan yang ditetapkan, maka tujuan dinyatakan berhasil

b. Apabila capaian diantara $49 \%$ sampai $74 \%$ dari tujuan yang ditetapkan, maka tujuan dinyatakan kurang berhasil

c. Apabila capaian hanya < 49\% kebawah dari tujuan yang ditetapkan, maka tujuan dinyatakan tidak berhasil.

2. Indikator yang digunakan dalam evaluasi adalah perubahan pengetahuan dan ketrampilan dalam penyusunan bahan ajar.

3. Tolak ukur yang digunakan dalam pelaksanaan evaluasi sesuai dengan apa yang dirumuskan pada tujuan pengabdian yang akan dilakukan.

\section{B. Prosedur Pelaksanaan}

Pelaksanaan kegiatan ini pertama mahasiswa dibagi kelompok menjadi empat kelompok yang masing-masing diketuai oleh seorang ketua kelompok dan terdiri dari tiga mahasiswa, kedua setiap kelompok dibagikan materi.

Siswa dibentuk menjadi beberapa kelompok, setiap keompok diberi materi berupa huruf Jepang yang berbeda-beda dengan kelompok lain, setiap kelompok mempunyai ketua dan anggota, dan setiap anggota masing kelompok mempelajari sub bagian kelompok yang sama, kemudian masing-masing ketua untuk mendiskusikan tugas pokok kelompok tersebut. Dan setiap anggota yang ditugaskan untuk berkumpul dengan kelompok lain belajar dengan materi yang sama, kemudian anggota masing- kelompok kembali ke kelompok masing-masingh kemudian menjelaskan apa yang dibahas pada materi yang sama tadi. Kemudian masing-masing ketua mempresentasikan hasil kelompok yang didiskusikan

$$
\text { Universitas Negeri Manado }
$$
(UNIMA) memiliki antara lain Lembaga Penelitian danPengabdian kepada Masyarakat (LPPM). LPPM UNIMA setiap 
tahun ada yang menang dalam kompetitif proposal pengabdian baik di Unima maupun di DP2M Dikti. Staf Dosen dari Fakultas Bahasa dan Seni setiap tahunnya mengusulkan usulan penelitian maupun pengabdidan kepada masyarakat. Dana yang tersedia telah diupayakan untuk memenuhi kebutuhan pelaksanaan tridharma perguruan tinggi walaupun jumlahnya masih dalam batas minimal untuk membiayai rencana kerja dan program-program yang telah dibuat yang termasuk dalam rencana staregis fakultas. upaya pengembangan dan peningkatan mutu.

Penelitian yang dilakukan pada Fakultas Bahasa dan Seni UNIMA untuk pengembangan program studi yang menunjang pencapaian visi dan misi fakultas dan universitas. Kualitas penelitian perlu ditingkatkan secara terus menerus. Kualitas penelitian juga turut dipengaruhi oleh ketersediaan dan besarnya dana yang ada. Walaupun adanya keterbatasan dana penelitian, dosen pada Fakultas Bahasa dan Senitetap efektif mengadakan penelitian, tidak selalu berharap pada ketersediaan dana. Dosen juga mengikuti kompetisi terhadap skim-skim penelitian yang ada, bekerja sama dengan dengan institusi lain, serta melalukan dengan swadana (biaya sediri).

\section{HASIL DAN PEMBAHASAN}

Kegiatan ini dilaksanakan pada tanggal 13-14 Juni 2019 dan diikuti oleh seluruh Guru-guru Bahasa Jepang yang ada di Manado. Tiap jenis media mempunyai karakteristik atau sifat-sifat khas tersendiri. Artinya mempunyai kelebihan dan kekurangan satu terhadap yang lain.Media Pembelajaran mempunyai Tujuan dan Manfaat yaitu.Dalam pemilihan media seorang pendidik diharapakan pandaipandai memilih dan memilah media yang akan digunakan dalam kegiatan belajar mengajar. Media pembelajaran yang akan digunakan harus menyesuaikan dengan umur siswa, keadaan siswa, situasi lingkunan belajar siswa, kemampuan siswa, dan waktu yang tepat.

\section{Fungsi dan Manfaat Media Pembelajaran}

Hamalik (dalam Arsyad, 2011:15) menjelaskan bahwa pemakaian media pembelajaran dalam proses belajar mengajar dapat membangkitkan keinginan dan minat yang baru, membangkitkan motivasi dan rangsangan kegiatan belajar, dan bahkan membawa pengaruh psikologis terhadap siswa. Penggunaan media pembelajaran pada tahap orientasi pembelajaran akan sangat membantu kefektivan proses pembelajaran dan penyampaian pesan dan isi pelajaran pada saat itu. Selain membangkitkan motivasi dan minat siswa, media pembelajaran juga 
dapat membantu mahasiswa meningkatkan pemahaman, menyajikan data dengan menarik dan terpercaya, memudahkan penafsiran data, dan memadatkan informasi.

Levie dan Lentz (dalam Arsyad, 2011:16) mengemukakan empat fungsi media pembelajaran, khususnya media visual yaitu, (1) fungsi atensi, merupakan inti, yaitu menarik dan mengarahkan perhatian mahasiswa untuk berkosentarasi kepada isi pelajaran yang berkaitan dengan makna viasual yang ditampilkan atau menyertai teks materi pelajaran. (2) fungsi afektif, media visual dapat terlihat dari tingkat kenikmatan mahasiswa ketika belajar atau membaca teks yang bergambar. Gambara atau lambang visual dapat menggugah emosi dan sikap siswa, misalnya informasi yang menyangkut masalah sosial atau ras. (3) fungsi kognitif, media visual terlihat dari temuan-temuan penelitian yang mengungkapkan lambang visual atau gambar memperlancar pencapaian tujuan untuk memahami dan mengingat informasi atau pesan yang terkandung dalam gambar. (4) fungsi kompensatoris, media pembelajaran terlihat dari hasil penelitian bahwa media visual yang memberikan konteks untuk memahami teks membantu mahasiswa yang lemah dalam membaca untuk mengorganisasikan informasi dalam teks dan mengingatnya kembali. Dengan kata lain, media pembelajaran berfungsi untuk mengakomodasikan mahasiswa yang lemah dan lambat menerima dan memahami isi pelajaran yang disajikan dengan teks atau disajikan secara verbal.

$$
\text { Berbagai manfaat media }
$$

pembelajaran telah dibahas oleh banyak ahli. Menurut Kemp dan Dayton (dalam Arsyad, 2011:21), meskipun telah lama disadari bahwa banyak keuntungan media pembelajaran, penerimaannya serta pengintegrasiannya kedalam programprogram pengajaran berjalan amat lambat. Mereka mengemukakan beberapa hasil penelitian yang menunjukan dampak dari penggunaan media sebagai bagian integral pembelajaran di kelas atau sebagai cara utama pembelajaran langsung sebagai berikut :

1. Penyampaian pelajaran menjadi lebih baku. Setiap pelajar yang melihat atau mendengar penyajian melalui media menerima pesan yang sama. Meskipun para guru menafsirkan isi pelajaran dengan cara yang berbeda-beda, dengan penggunaan media ragam hasil tafsiran itu dapat dikurangi sehingga ragam hasil tafsiran itu dapat disampaikan kepada mahasiswa sebagai landasan untuk pengkajian, latihan dan aplikasi lebih lanjut.

2. Pembelajaran bisa lebih menarik. Media dapat diasosiasikan sebagai penarik perhatian dan membuat mahasiswa tetap terjaga dan memperhatikan. 
3. Pembelajaran menjadi lebih interaktif dengan diterapkannya teori belajar dan prinsip-prinsp psikologis yang diterima dalam hal partisipasi siswa, umpan balik, dan penguatan.

4. Lama waktu pembelajaran yang diperlukan dapat dipersingkat karena kebanyakan media hanya memerlukan waktu singkat untuk mengantarkan pesan-pesan dan isi pelajaran dalam jumlah yang cukup banyak dan kemungkinannya dapat diserap oleh siswa.

5. Sikap positif mahasiswa terhadap apa yang mereka pelajari dan terhadap proses belajar dapat ditingkatkan.

6. Peran guru dapat verubah kearah lebih positif, beban guru untuk penjelasan yang berulang-ulang mengenai isi pelajaran dapat dikurangi bahkan dihilangkan sehingga ia dapat memusatkan perhatian kepada aspek penting lain dalam proses belajar mengajar, misalnya sebagai konsultan atau penasehat siswa.

Manfaat Media Pembelajaran Arsyad ( 1996 :15) mengemukakan bahwa fungsi utama media pendidikan atau media pembelajaran adalah sebagai alat bantu mengajar yang turut mempengaruhi iklim, kondisi dan lingkungan belajar yang ditata dan diciptakan oleh guru. Sanjaya (200 : 167), media pembelajaran memiliki fungsi dan peran untuk :
1. Menangkap suatu objek atau peristiwa peristiwa tertentu.

2. Memanipulasi keadaan, peristiwa atau objek tertentu.

3. Menambah gairah dan motivasi

Metode yang digunakan dalam kegiatan penyuluhan yang dilaksanakan relevan dengan pokok permasalahan yang disesuaikan dengan tujuan yang ingin dicapai adalah yaitu metode presentasi, tanya jawab, demonstrasi dan pemberian tugas.

Sebelum kita gunakan, media harus kita pilih secara cermat. Memilih media yang terbaik untuk tujuan pembelajaran bukanlah pekerjaan yang mudah. Pemilihan itu rumit dan sulit, karena harus mempertimbangkan berbagai faktor.

1. Model pemilihan media

Anderson (1976) mengemukakan adanya dua pendekatan/model dalam proses pemilihan media pembelajaran, yaitu: model pemilihan tertutup dan model pemilihan terbuka. Pemilihan tertutup terjadi apabila alternatif media telah ditentukan "dari atas" (misalnya oleh Dinas Pendidikan), sehingga mau tidak mau jenis media itulah yang harus dipakai. Kalau toh kita memilih, maka yang kita lakukan lebih banyak ke arah pemilihan topik/pokok bahasan mana yang cocok untuk dimediakan pada jenis tertentu. Misalnya saja, telah ditetapkan bahwa media yang digunakan adalah media audio. Dalam situasi damikian, bukanlah 
mempertanyakan mengapa media audio yang digunakan, dan bukan media lain? Jadi yang harus kita lakukan adalah memilih topik-topik apa saja yang tepat untuk disajikan melalui media audio. Untuk model pemilihan terbuka, lebih rumit lagi.

Model pemilihan terbuka merupakan kebalikan dari pemilihan tertutup. Artinya, kita masih bebas memilih jenis media apa saja yang sesuai dengan kebutuhan kita. Alternatif media masih terbuka luas. Proses pemilihan terbuka lebih luwes sifatnya karena benar-benar kita sesuaikan dengan kebutuhan dan kondisi yang ada. Namun proses pemilihan terbuka ini menuntut kemampuan dan keterampilan guru untuk melakukan proses pemilihan. Seorang guru kadang bisa melakukan pemilihan media dengan mengkombinasikan antara pemilihan terbuka dengan pemilihan tertutup.

2. Mengapa perlu pemilihan media?

Media pada hakekatnya merupakan salah satu komponen sistem pembelajaran. Sebagai komponen, media hendaknya merupakan bagian integral dan harus sesuai dengan proses pembelajaran secara menyeluruh. Akhir dari pemilihan media adalah penggunaaan media tersebut dalam kegiatan pembelajaran, sehingga memungkinkan siswa dapat berinteraksi dengan media yang kita pilih.

Apabila kita telah menentukan alternatif media yang akan kita gunakan dalam pembelajaran, maka pertanyaan berikutnya adalah sudah tersediakah media tersebut di sekolah atau di pasaran? Jika sudah tersedia, maka kita tinggal meminjam atau membelinya saja. Itupun jika media yang ada memang sesuai dengan tujuan pembelajaran yang telah kita rencanakan, dan terjangkau harganya. Jika media yang kita butuhkan temyata belum tersedia, mau tak mau kita harus membuat sendiri program media sesuai keperluan tersebut.

Jadi, pemilihan media itu perlu kita lakukan agar kita dapat menentukan media yang terbaik, tepat dan sesuai dengan kebutuhan dan kondisi sasaran didik. Untuk itu, pemilihan jenis media harus dilakukan dengan prosedur yang benar, karena begitu banyak jenis media dengan berbagai kelebihan dan kelemahan masing-masing.

\section{Hakikat Belajar dan Pembelajaran}

Pengajaran merupakan suatu kegiatan atau upaya membantu para siswa mengembangkan kemampuan, pengetahuan, dan keterampilan dalam suatu bidang tertentu, Ibrahim dan Syaodih (1992:2) kegiatan pengajaran tidak sesederhana membeli pakaian. Walaupun tidak sekompleks membangun sebuah kota, tetapi kegiatan ini membutuhkan perencanaan yang seksama dan dibuat secara tertulis.

Dengan lajunya perkembangan dewasa 
ini khususnya dalkam bidang pendidikan, telah banyak ahli yang mengungkapkan tentang teori belajar.Para ahli pendidikan telah berusaha merumuskan definisi tentang belajar dilihat dari berbagai segi.Berikut ini dikemukakan tentang beberapa pendapat para ahli mengenai pengertian belajar itu.

Para ahli mengenai teori belajar modern menemukakan dan merumuskan pengertian belajar sebagai berikut, belajar adalah suatu bentuk perubahan dalam diri seseorang yang dinyatakan dalam cara-cara bertingkah laku yang baru berkat pengalaman dan latihan (Hamalik, 1982:28).Tingkah laku yang baru itu misalnya dari tidak tahu menjadi tahu, timbulnya pengertianpengertian baru, perubahan dalam sikap, kebiasaan-kebiasaan, keterampilan, kesanggupan menghargai, perkembangan sifat-sifat sosial emosional, dan pertumbuhan jasmani.

Evaluasi dilakukan mulai awal pelatihan sampai akhir pelatihan. Kriteria, indicator dan tolak ukur evaluasinya adalah sebagai berikut :

\section{KESIMPULAN DAN SARAN}

\section{Kesimpulan}

Pembelajaran menyenangkan artinya pembelajaran yang interaktif dan atraktif, sehingga anak didik dapat memusatkan perhatian terhadap pembelajaran yang sedang dijalaninya. Dalam pemilihan media seorang pendidik diharapakan pandai-pandai memilih dan memilah media yang akan digunakan dalam kegiatan belajar mengajar. Media pembelajaran yang akan digunakan harus menyesuaikan dengan umur siswa, keadaan siswa, situasi lingkunan belajar siswa, kemampuan siswa, dan waktu yang tepat.Tiap jenis media mempunyai karakteristik atau sifat-sifat khas tersendiri. Artinya mempunyai kelebihan dan kekurangan satu terhadap yang lai. Sifatsifat yang biasanya dipakai untuk menentukan kesesuaian penggunaan atau pemilihan media ialah:Jangkauan, Keluwesan, Ketergantungan dan Atribut.

Kegiatan pengabdian pada masyarakat dalam bentuk pelatihan penggunaan media pembelajaran yang bervariasi kepada Guru-guru Bahasa Jepang MGMP Manado telah berhasil dilaksanakan dengan baik. Pelaksanaan pelatihan ini telah mencapai tujuan yang dilaksanakan karena semua peserta dapat menguasai dan membuat media pembelajaran yang bervariasi

\section{Saran}

Melihat Apabila capaian nilai > 75\% dari tujuan yang ditetapkan, maka tujuan dinyatakan berhasil. keberhasilan yang diperoleh serta antusiasnya peserta dalam kegiatan pengabdian pada masyarakat dalam bentuk pelatihan berupa kusus singkat seperti ini sangat bagus dan positif bagi pengembangan profesionalitas guru. Penulis merasa perlu ditindak lanjuti pada lokasi yang sama maupun lokasi yang lain dengan topic/materi yang berbeda, 
mengapa dikatakan demikian karena hal ini dapat meningkatkan rasa percaya diri terutama bagi para guru sehingga menjadi guru yang profesional dalam mengajar di depan kelas.

\section{KEPUSTAKAAN}

Azwar Saifuddin. 1999. Metode Penelitian, Yogyakarta: Pustaka Pelajar.

Arikunto, Suharsimi, 1998. Prosedur

Penelitian: Suatu Pendekatan

Praktek, Jakarta: PT Rineka Cipta.
3A Corporation. 2000. Minna No Nihongo Kosa kata bahasa Jepang I ( English Edition),Tokyo. 3A Corporation.

Chandra. T 2000. Mengenal Kosa kata bahasa Jepang, Jakarta : Evergreen Japanese Course

Dwiloka Bambang, Riana Rati. 2005. Teknik Menulis Karya Ilmiah, Jakarta: Rineka Cipta.

Hartanto, B., \& Wijaya, 2004. F., The Magic of Flash MX 2004, Jakarta: PT. Elex Media Komputindo

Sadewa, Yoel, 2004 Bahasa Jepang Yang Mudah Yasahii Nihongo, Media Abadi, Yogyakarta

Widodo, Edi. 2006. Multimedia dan Pembelajaran Bahasa. Bandung 